\title{
EVALUATION OF SPECIFIC ABSORPTION RATE OF ELECTROMAGNETIC RADIATION ON HUMAN BRAIN - MICROSTRIP PATCH ANTENNA
}

\author{
P.R. Arul Jenshiya, K. Madhan Kumar and H. Riyaz Fathima \\ Department of Electronics and Communication Engineering, PET Engineering College, India
}

\begin{abstract}
This paper presents the evaluation of specific absorption rate for human head by designing rectangular shaped microstrip patch antenna. An antenna is a transducer that converts electrical signals into EM waves and radiates into space. The performance of an antenna is measured by its parameters namely bandwidth, gain, return loss etc. There are several types of antennas available but the microstrip patch antennas are widely used for many applications because of its low profile, light weight, low cost, feed-line flexibility, versatility, ease of fabrication etc. Even though it has several advantages, it suffers from major drawbacks namely narrow bandwidth, low gain and high return loss. In order to overcome these drawbacks, FR-4 materials are used. Specific absorption rate (SAR) is a measurement of certain amount of radiation absorbed by human body while entering into an electromagnetic field. It is defined as the power absorbed per mass of tissue and has units of a watt per kilogram. SAR is typically averaged either over the complete body or over a small sample volume (typically $1 \mathrm{~g}$ or $10 \mathrm{~g}$ of tissue). For evaluating the antenna performance, gain, VSWR and the return loss were calculated for the proposed antenna and the proposed antenna provides the peak the gain of $4.43 \mathrm{~dB}$ at $10.846 \mathrm{GHz}$. The proposed antenna also provides the SAR value of $0.00109 \mathrm{~W} / \mathrm{Kg}$ is evaluated for $1 \mathrm{~g}$ of tissue as per the IEEE standard. The human head model and the proposed antennas are designed using CST (Computer Simulation Technology) microwave studio tool.
\end{abstract}

Keywords:

Voltage Standing Wave Ratio, Gain, Return Loss, Specific Absorption Rate

\section{INTRODUCTION}

The advent of science and technology maximized the use of mobile phones. The integration between the human body and mobile phones plays an important aspect in this world of cutting edge technology. The emission of EM waves dissipated from mobile has been a cause of major concern [9]. To ensure the human safety the International Commission on Non- Ionizing Radiation Protection (ICNIRP) and Institute of Electrical and Electronics Engineers (IEEE) has established certain guidelines and standards for limiting the electromagnetic field exposure from mobile phones as well as other communication devices. This standard provides basic limits for SAR (Specific Absorption Rate), the devices or mobile phones which are operated above the defined limits should not be permitted for usage. The permitted SAR value in India is $1.6 \mathrm{~W} / \mathrm{kg}$ [1]. SAR is a measurement at which radiation from mobile phones is absorbed by the human body when exposed to an electromagnetic field. Unit of SAR is watt per kilogram $(\mathrm{W} / \mathrm{Kg})$ [2]. The equation for manual SAR calculation is given below

$$
S A R=\left(\sigma E^{2}\right) /(2 \rho)
$$

where,

$\sigma$ - conductivity of tissue (S/m)

\section{$E$ - Electric field strength of tissue $(\mathrm{V} / \mathrm{m})$}

$\rho$ - Mass density $\left(\mathrm{Kg} / \mathrm{m}^{3}\right)$

When humans are affected by radiation the properties of human body such as conductivity and temperature is changed. But to measure those changes inside the human body is very difficult. When the temperature of the human body is increased it leads to certain health effects or the radiation absorbed by human body will damage the human tissue. Since the radiation from any devices may not be uniform for that the IEEE standard or ICNIRP provides certain limits of radiation emission form communication devices.

There are two types of antennas inside the mobile device such as microstrip patch antenna and Planar Inverted F-Antenna (PIFA) [6], [8], [10]. The microstrip patch antenna provides better performance than PIFA antenna. Antenna performance parameters such as gain, VSWR, return loss, directivity, E-field, $\mathrm{H}$-field and power are necessary for the testing of mobile phones. The radiation absorbed by the six-layer human head [3]-[4] can be verified by a numerical method based on finite difference time domain technique [7] using CST (Computer Simulation Technology) microwave studio software.

\section{LITERATURE REVIEW}

The rectangular shaped microstrip patch antenna operates at the frequency band from $2.3 \mathrm{GHz}$ to $4.46 \mathrm{GHz}$. It is designed with slot and the head model is kept at a distance of $50 \mathrm{~mm}$ from the antenna and SAR is calculated. The simulation is done using CST microwave studio electromagnetic simulation tool. The designed antenna provides the return loss of $-25 \mathrm{~dB}$ for $4.46 \mathrm{GHz}$. The evaluated SAR value is $0.06399 \mathrm{~W} / \mathrm{Kg}$ for $10 \mathrm{~g}$ of tissue which is well within the limits provided by the FCC [5].

The square patch antenna is designed for the wireless applications of frequency band from 1 to $6 \mathrm{GHz}$. It uses the thick and low dielectric constant material as substrate. From the designed SPA the SAR value is $0.176 \mathrm{~W} / \mathrm{Kg}$ for $10 \mathrm{~g}$ of adult human head tissues [2].

From the above literature review, it is found that the antenna operated at a lower frequency band, so our designed rectangular shaped microstrip patch antenna operated at a higher frequency band from $10.846 \mathrm{GHz}$ to $16.452 \mathrm{GHz}$ and reduces its size by loading FR-4 (Flame Retardant) as a substrate material.

This work endeavors to analyze the antenna performance such as the gain, VSWR, return loss and also includes the observation of specific absorption rate for the human phantom (tissue) with the same environment.

The Fig. 1 shows the data flow graph of an antenna design and human head model they are designed using CST software. In this paper two types of antennas and its radiation characteristics are 
analyzed in terms of SAR. The designed antennas are verified under the frequency range from $10.846 \mathrm{GHz}-16.452 \mathrm{GHz}$.

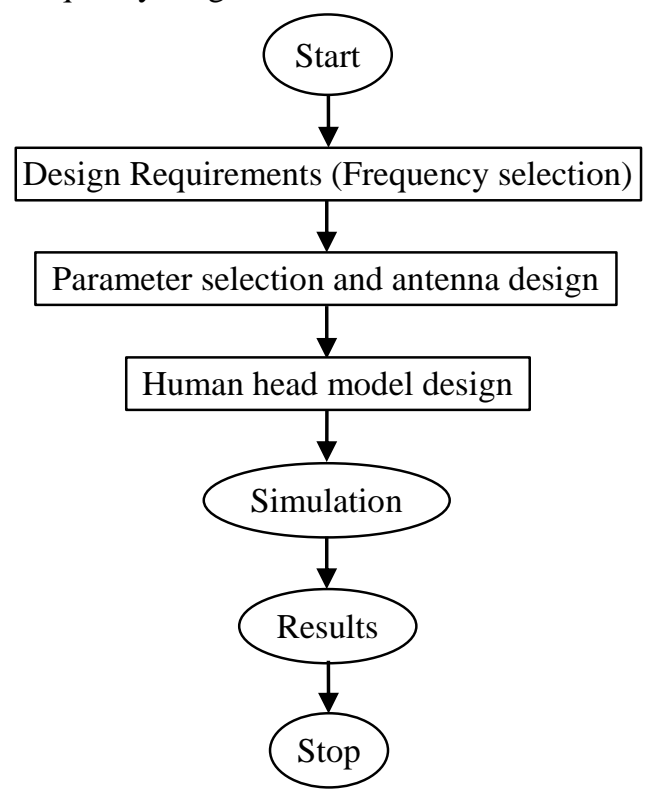

Fig.1. Data Flow Diagram

\section{ANTENNAS AND HEAD MODEL DESIGN}

Rectangular microstrip patch antennas are designed with the following essential parameters:

- Operating frequency $\left(f_{0}\right)$

- Substrate dielectric constant $\left(\varepsilon_{r}\right)$

The frequency of operation in this design is $10.846 \mathrm{GHz}$ to $16.452 \mathrm{GHz}$. In this section, rectangular shape microstrip patch antenna are designed using copper (annealed) material as ground and the FR-4 (Flame Retardant) material is used to design the substrate which consist of fiberglass and epoxy resin for efficient communication between ground and patch.

The patch is loaded over the substrate which is designed using copper (annealed) material. The slot cuts in these designed antennas are made with nickel (lossy) material.

\subsection{VERTICAL SLOT MICROSTRIP PATCH ANTENNA}

The vertical slot rectangular shaped microstrip patch antenna is designed as ground, substrate, patch and the feed for the designed antenna is microstrip line feed with the dimensions of width and length is $2 \mathrm{~mm}$ and $5 \mathrm{~mm}$ respectively. The ground and substrate are designed with the same dimensions of width and length is $14 \mathrm{~mm}$ and $18 \mathrm{~mm}$ but its thickness is varied. The thickness for the ground is $0.05 \mathrm{~mm}$ and the thickness for the substrate is $1.40 \mathrm{~mm}$. The top layer of the designed antenna is made with 3 sets of patches and their dimensions are given as fallows

- Top patch: Length-7mm, Width-10mm, Thickness-0.05mm.

- Left bottom patch: Length-3mm, Width-8mm, Thickness$0.05 \mathrm{~mm}$

- Right bottom patch: Length-3mm, Width-8mm, Thickness$0.05 \mathrm{~mm}$
The designed vertical slot rectangular shaped microstrip path antenna consists of 2 slots as slot 1 and slot 2 and they are made up of nickel (lossy) material. The slot1 and slot2 has the same dimensions but they differ only with the position. The width, length and thickness of the slot 1 and slot 2 is $2.5 \mathrm{~mm}, 5 \mathrm{~mm}$ and $0.05 \mathrm{~mm}$ which is shown in below Fig.2.

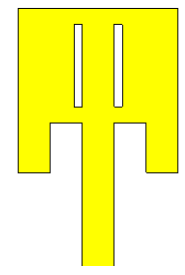

Fig.2. Vertical slot microstrip patch antenna

\subsection{CYLINDRICAL SLOT MICROSTRIP PATCH ANTENNA}

The cylindrical slot rectangular shaped microstrip patch antenna is designed with the same dimensions of the vertical slot microstrip patch antenna ground, substrate, patch and feed. Fig.3 shows the cylindrical slot MPA, the cylindrical slot is designed in polygon shape with thickness of $0.05 \mathrm{~mm}$ and inner radius of the slot is $1 \mathrm{~mm}$ and outer radius of the slot is $2 \mathrm{~mm}$.

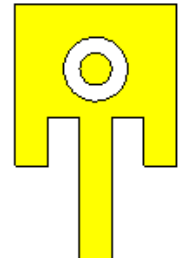

Fig.3. Cylindrical slot microstrip patch antenna

\subsection{HUMAN HEAD MODEL DESIGN}

The human brain is the central core for the nervous system it controls the functions of the whole body. If the human head absorbs large amount of radiation it leads to certain health effects which also alter the basic biological cell functions of the human body. In this paper the human head model is designed with 6 layers (Scalp, Fat, Skull, Dura, CSF and Brain). The amount of radiation absorbed by the human head can be evaluated as SAR. The SAR can be evaluated as 2 sets one is calculating the SAR value by placing an antenna near to the head and the another one is by placing an antenna far away from the human head model with $10 \mathrm{~m}$ distance. The average mass density and conductivity of these layers are: $\operatorname{scalp}(R h o=1010 ; \sigma=0.87)$, fat $(R h o=920 ; \sigma=$ $0.11)$, skull $(R h o=1810 ; \sigma=0.32)$, Dura $(R h o=1040 ; \sigma=0.94)$, CSF $(R h o=1010 ; \sigma=2.12)$, and Brain $(R h o=1030 ; \sigma=0.86)$. The thickness of Scalp, Fat, Skull, Dura, CSF and Brain layers are $1 \mathrm{~mm}, 1.5 \mathrm{~mm}, 2 \mathrm{~mm}, 2.5 \mathrm{~mm}, 3 \mathrm{~mm}$ and $4 \mathrm{~mm}$ respectively. The designed head model is shown in Fig.4. 


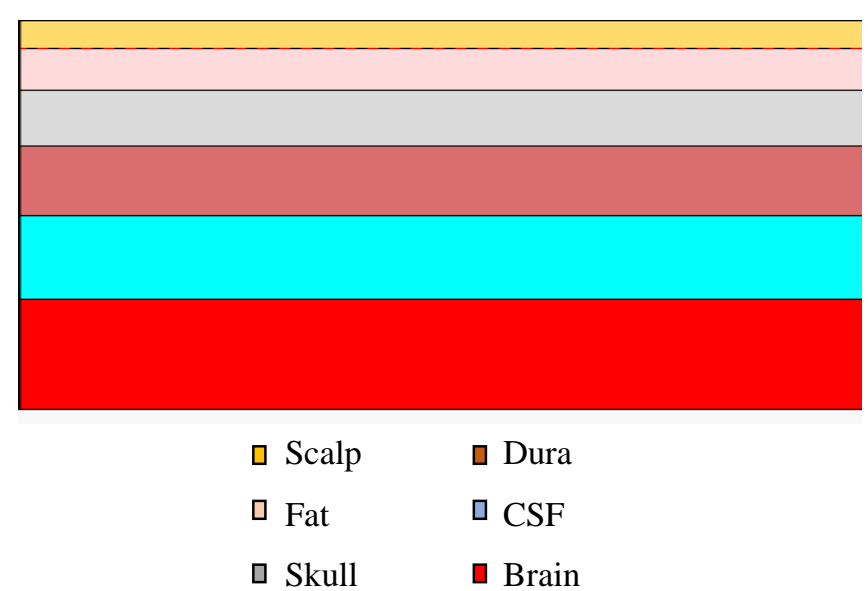

Fig.4. Human head model

In this proposed work, two types of antennas are designed and its parameters such as gain, VSWR, return loss and SAR value is evaluated for the human head model with placing an antenna near and far.

\section{RESULTS}

\subsection{VERTICAL SLOT MICROSTRIP PATCH ANTENNA}

The Fig.5 and Fig.6 shows the return loss of vertical slot rectangular shaped microstrip patch antenna placed at close proximity and far proximity. Vertical slot RMPA at close proximity provides Return loss of $-12.03 \mathrm{~dB}$ at $11.481 \mathrm{GHz}$. Vertical slot RMPA at far proximity provides Return loss of $-13.694 \mathrm{~dB}$ at $11.388 \mathrm{GHz}$.

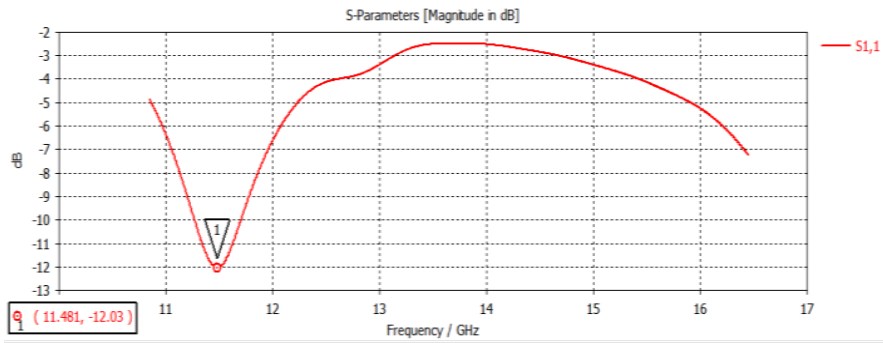

Fig.5. Return loss of vertical slot RMPA at close proximity

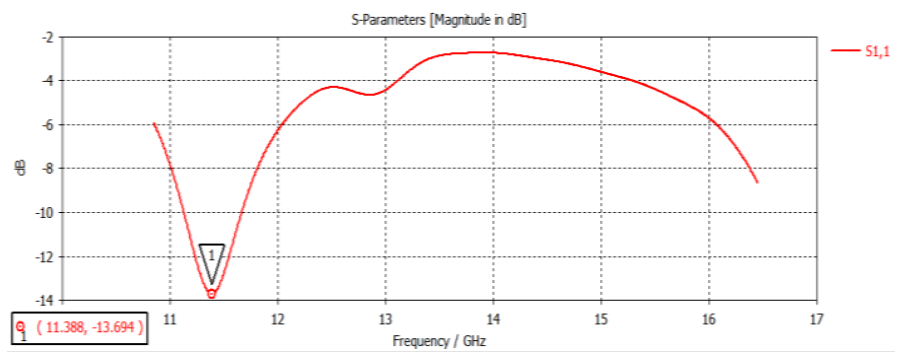

Fig.6. Return loss of vertical slot RMPA at far proximity

The Fig.7 and Fig.8 shows the gain of vertical slot rectangular shaped microstrip patch antenna placed at close proximity and far proximity. Vertical slot RMPA at close proximity provides gain of $2.83 \mathrm{~dB}$ at $10.846 \mathrm{GHz}$ and $1.82 \mathrm{~dB}$ at $16.452 \mathrm{GHz}$. At far proximity Fig.9 and Fig. 10 shows the gain of $4.2 \mathrm{~dB}$ at $10.846 \mathrm{GHz}$ and $2.48 \mathrm{~dB}$ at $16.452 \mathrm{GHz}$.

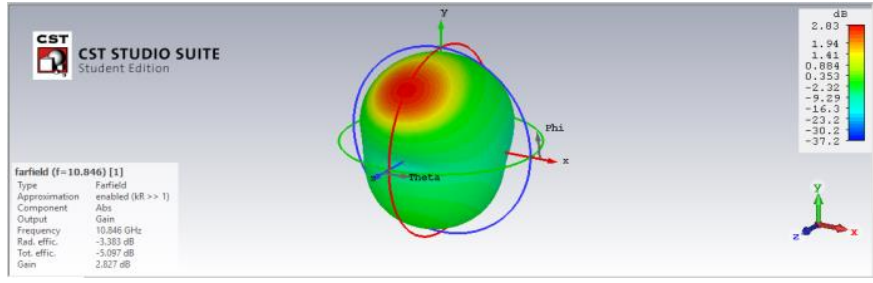

Fig.7. Close proximity Gain for Vertical slot RMPA at $10.846 \mathrm{GHz}$

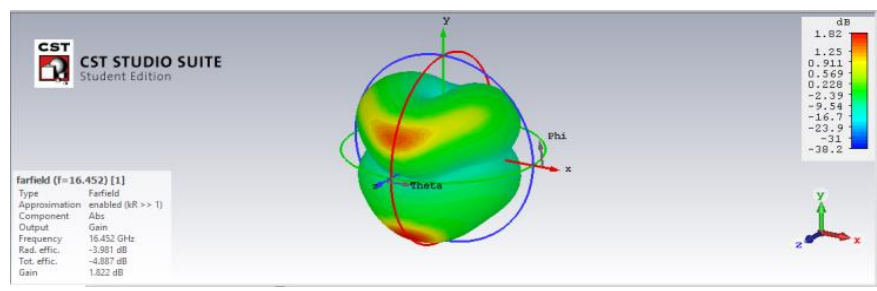

Fig.8. Close proximity Gain for Vertical slot RMPA at $16.452 \mathrm{GHz}$

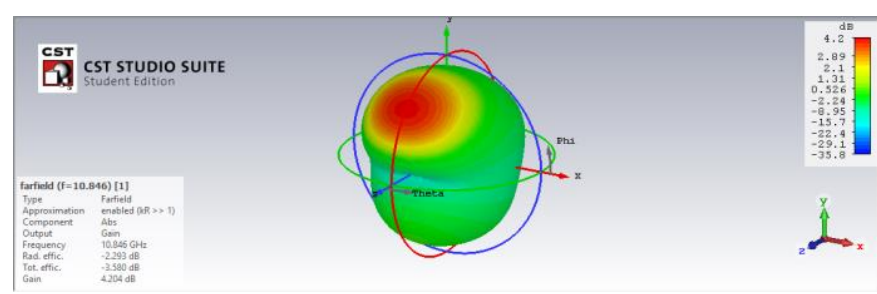

Fig.9. Far proximity Gain for Vertical slot RMPA at $10.846 \mathrm{GHz}$

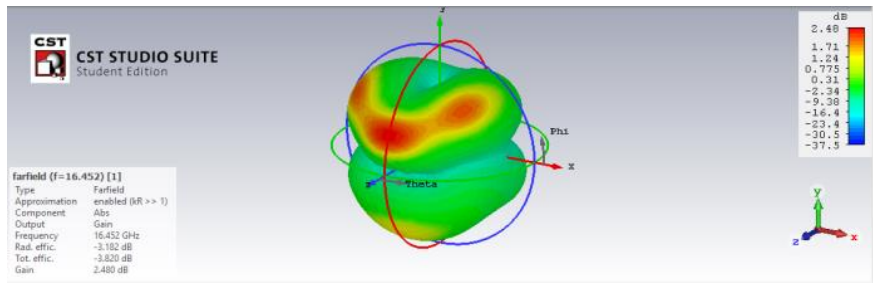

Fig.10. Far proximity Gain for Vertical slot RMPA at $16.452 \mathrm{GHz}$

The Fig.11 and Fig.12 shows the VSWR value for vertical slot RMPA at close proximity and far proximity. At close proximity vertical slot RMPA provides VSWR of 1.6698 at $11.463 \mathrm{GHz}$. At far proximity vertical slot RMPA provides VSWR of 1.5213 at $11.393 \mathrm{GHz}$.

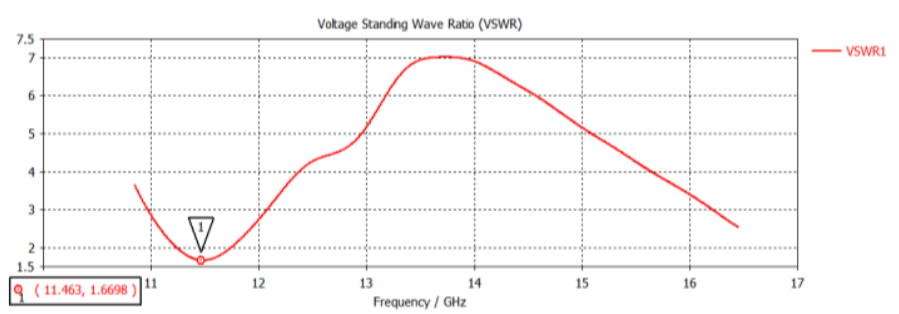

Fig.11. Close proximity VSWR for vertical slot RMPA 


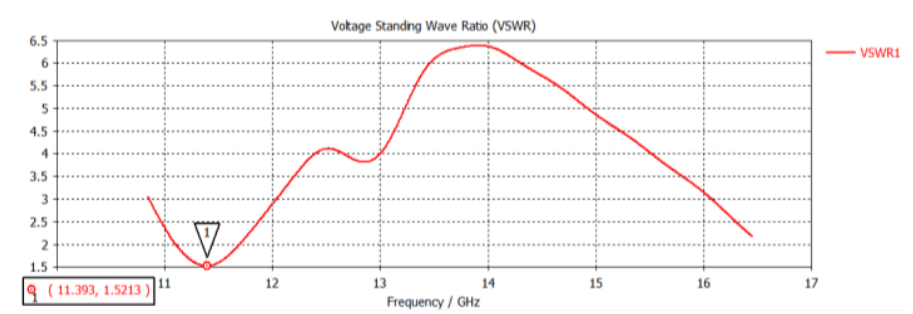

Fig.12. Far proximity VSWR for vertical slot RMPA

The Fig.13 and Fig.14 shows the SAR value for $1 \mathrm{~g}$ of tissue when an antenna is placed close to the human head model with frequency of 10.846 and 16.452 which provides the SAR value of $0.0309 \mathrm{~W} / \mathrm{Kg}$ at $10.846 \mathrm{GHz}$ and $0.019 \mathrm{~W} / \mathrm{Kg}$ at $16.452 \mathrm{GHz}$.

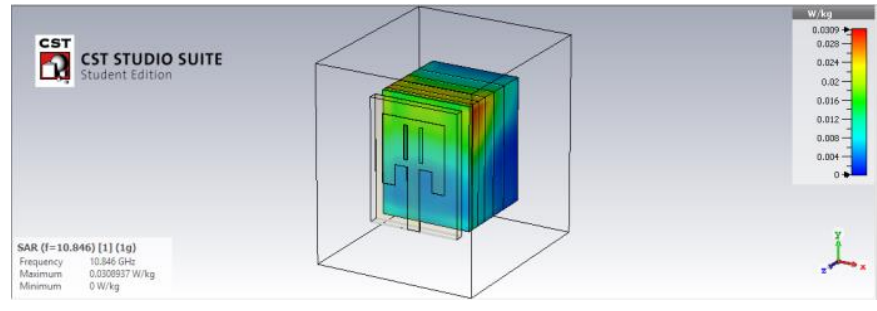

Fig.13. SAR for $1 \mathrm{~g}$ of tissue at close proximity-10.846GHz

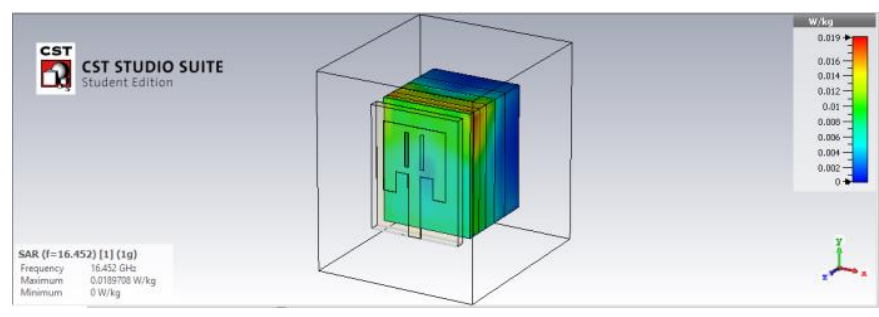

Fig.14. SAR for $1 \mathrm{~g}$ of tissue at close proximity-16.452GHz

The Fig.15 and Fig.16 shows the SAR value for $1 \mathrm{~g}$ of tissue when an antenna is placed far away from the human head model with frequency of 10.846 and 16.452 which provides the SAR value of $0.00851 \mathrm{~W} / \mathrm{Kg}$ at $10.846 \mathrm{GHz}$ and $0.00159 \mathrm{~W} / \mathrm{Kg}$ at $16.452 \mathrm{GHz}$.

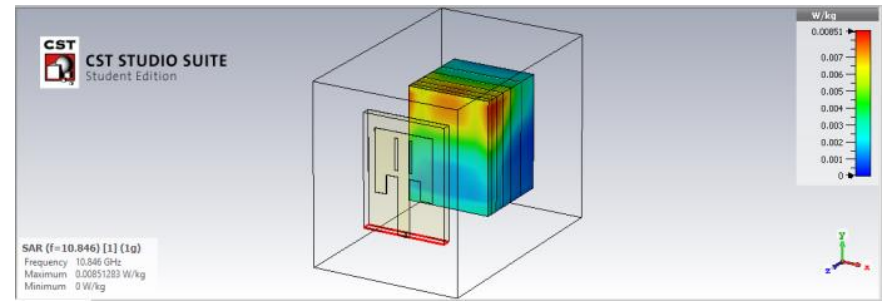

Fig.15. SAR for $1 \mathrm{~g}$ of tissue at far proximity-10.846GHz

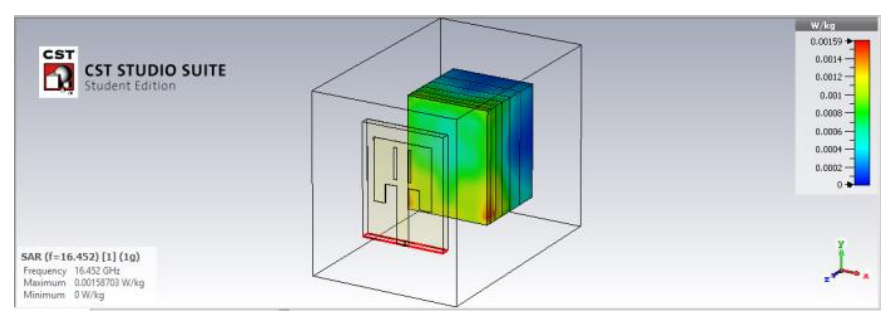

Fig.16. SAR for $1 \mathrm{~g}$ of tissue at far proximity-16.452GHz

\subsection{CYLINDRICAL SLOT MICROSTRIP PATCH ANTENNA}

The Fig.17 and Fig.18 shows the return loss of cylindrical slot rectangular shaped microstrip patch antenna placed at close proximity and far proximity. Cylindrical slot RMPA at close proximity provides return loss of $-18.552 \mathrm{~dB}$ at $11.906 \mathrm{GHz}$. Cylindrical slot RMPA at far proximity provides return loss of $-25.081 \mathrm{~dB}$ at $11.631 \mathrm{GHz}$.

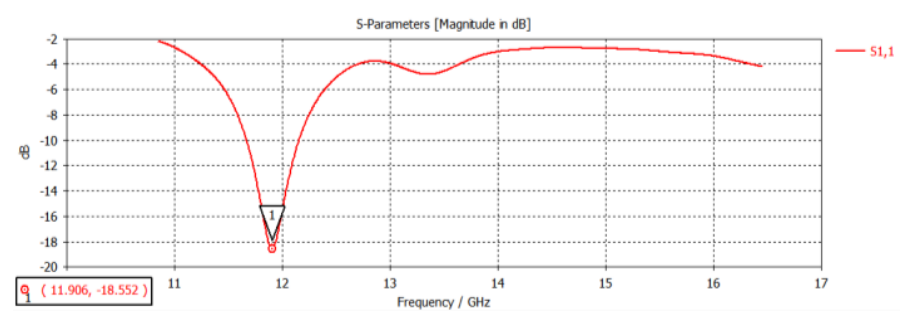

Fig.17. Return loss of cylindrical slot RMPA at close proximity

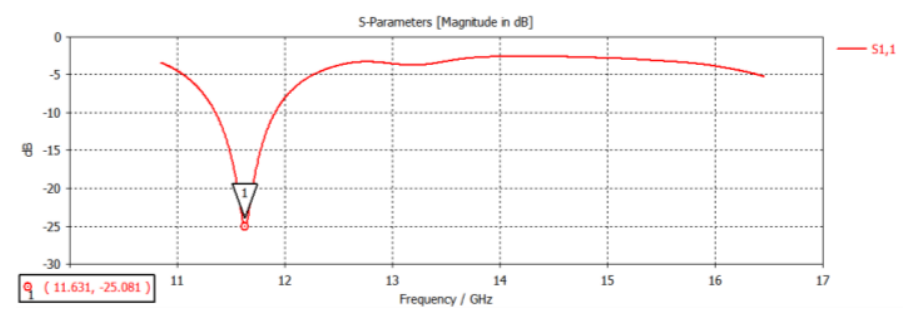

Fig.18. Return loss of cylindrical slot RMPA at far proximity

The Fig.19 and Fig.20 shows the gain of cylindrical slot rectangular shaped microstrip patch antenna placed at close proximity and far proximity. Cylindrical slot RMPA at close proximity provides gain of $3.06 \mathrm{~dB}$ at $10.846 \mathrm{GHz}$ and $2.19 \mathrm{~dB}$ at 16.452GHz. At far proximity, Fig.21 and Fig.22 shows the gain of $4.43 \mathrm{~dB}$ at $10.846 \mathrm{GHz}$ and $3.41 \mathrm{~dB}$ at $16.452 \mathrm{GHz}$.

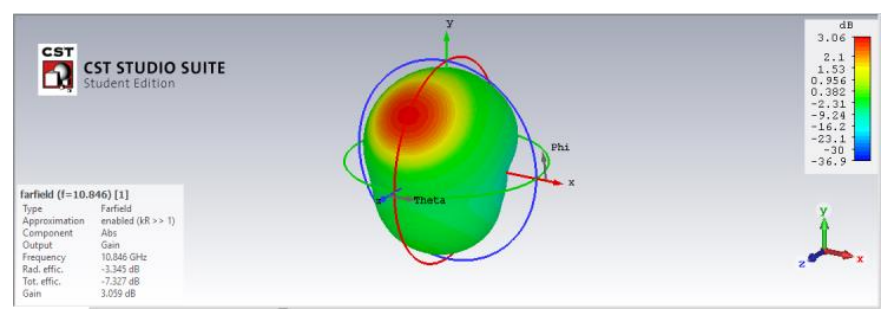

Fig.19. Close proximity gain for cylindrical slot RMPA at $10.846 \mathrm{GHz}$

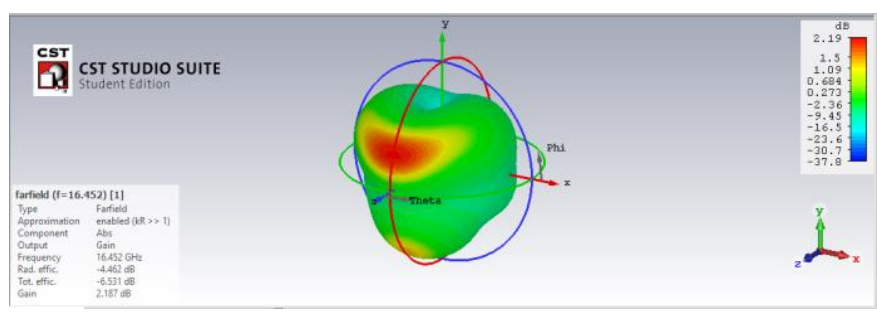

Fig.20. Close proximity gain for cylindrical slot RMPA at $16.452 \mathrm{GHz}$ 


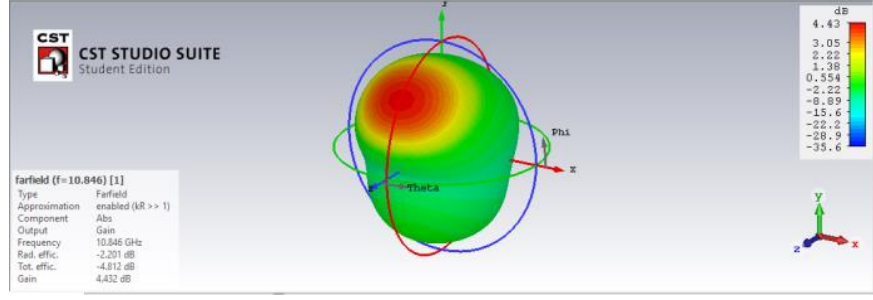

Fig.21. Far proximity gain for cylindrical slot RMPA at $10.846 \mathrm{GHz}$

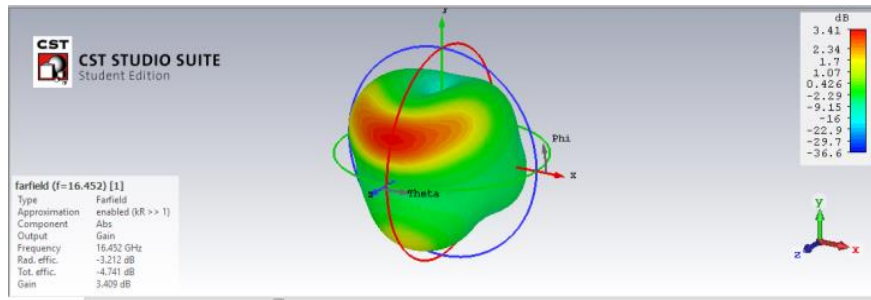

Fig.22. Far proximity gain for cylindrical slot RMPA at $16.452 \mathrm{GHz}$

The Fig.23 and Fig.24 shows the VSWR value for cylindrical slot RMPA at close proximity and far proximity. At close proximity cylindrical slot RMPA provides VSWR of 1.2681 at 11.907GHz. At far proximity cylindrical slot RMPA provides VSWR of 1.1181 at $11.631 \mathrm{GHz}$

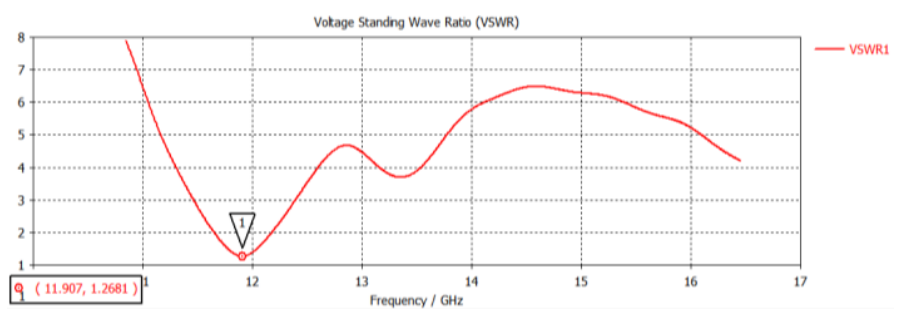

Fig.23. Close proximity VSWR for cylindrical slot RMPA

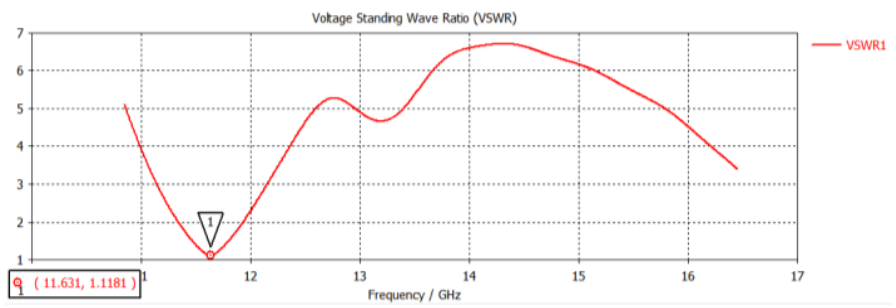

Fig.24. Far proximity VSWR for cylindrical slot RMPA

The Fig.25 and Fig.26 shows the SAR value for $1 \mathrm{~g}$ of tissue when an antenna is placed close to the human head model with frequency of 10.846 and 16.452 which provides the SAR value of $0.0149 \mathrm{~W} / \mathrm{Kg}$ at $10.846 \mathrm{GHz}$ and $0.0204 \mathrm{~W} / \mathrm{Kg}$ at $16.452 \mathrm{GHz}$.

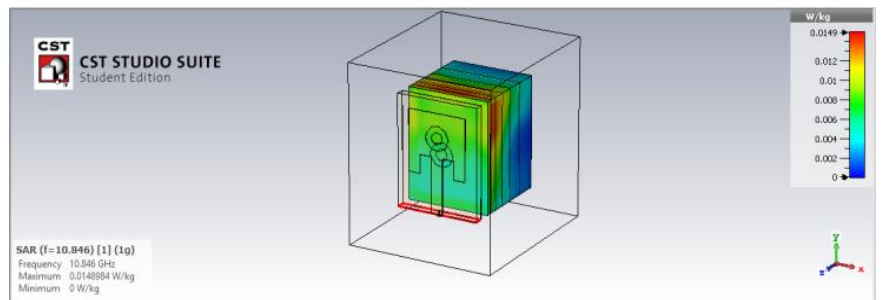

Fig.25. SAR for $1 \mathrm{~g}$ of tissue at close proximity-10.846GHz

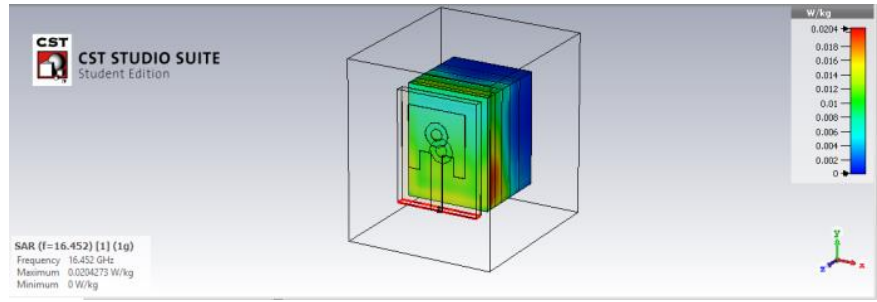

Fig.26. SAR for $1 \mathrm{~g}$ of tissue at close proximity $-16.452 \mathrm{GHz}$

The Fig.27 and Fig.28 shows the SAR value for $1 \mathrm{~g}$ of tissue when an antenna is placed far away from the human head model with frequency of 10.846 and 16.452 which provides the SAR value of $0.00546 \mathrm{~W} / \mathrm{Kg}$ at $10.846 \mathrm{GHz}$ and $0.00109 \mathrm{~W} / \mathrm{Kg}$ at $16.452 \mathrm{GHz}$.

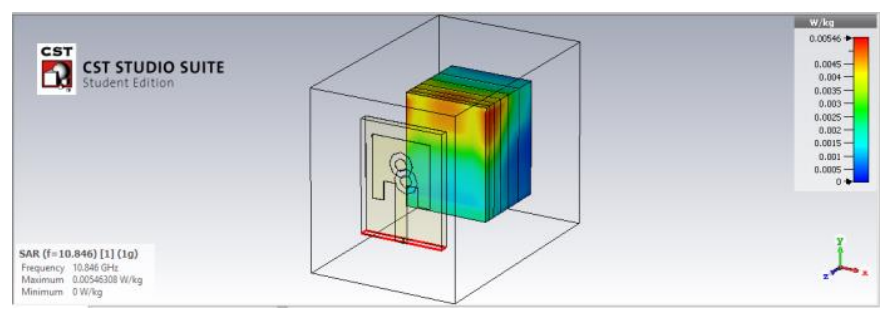

Fig.27. SAR for $1 \mathrm{~g}$ of tissue at far proximity-10.846GHz

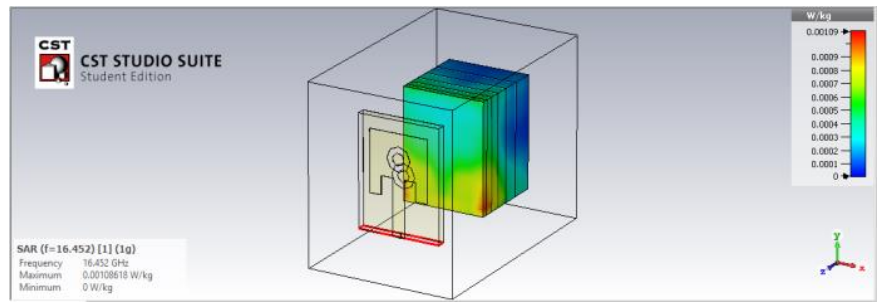

Fig.28. SAR for $1 \mathrm{~g}$ of tissue at far proximity $-16.452 \mathrm{GHz}$

Table.1. Results of the proposed antennas

\begin{tabular}{|c|c|c|c|c|}
\hline \multirow{2}{*}{ Antennas } & \multicolumn{2}{|c|}{ Return loss (dB) } & \multicolumn{2}{c|}{ VSWR } \\
\cline { 2 - 5 } & $\begin{array}{c}\text { Close } \\
\text { proximity }\end{array}$ & $\begin{array}{c}\text { Far } \\
\text { proximity }\end{array}$ & $\begin{array}{c}\text { Close } \\
\text { proximity }\end{array}$ & $\begin{array}{c}\text { Far } \\
\text { proximity }\end{array}$ \\
\hline $\begin{array}{c}\text { Vertical slot } \\
\text { MPA }\end{array}$ & -12.03 & -13.694 & 1.6698 & 1.5213 \\
\hline $\begin{array}{c}\text { Cylindrical } \\
\text { slot MPA }\end{array}$ & -18.552 & -25.081 & 1.2681 & 1.1181 \\
\hline
\end{tabular}

From Table.2, it is observed that the cylindrical slot microstrip patch antenna provides less return loss of $-18.552 \mathrm{~dB}$ when an antenna is placed close to the human head and $-25.081 \mathrm{~dB}$ at far proximity. The cylindrical slot micro strip patch antenna also provides less VSWR 1.2681 at close proximity and 1.1181 at far proximity.

From Table.3, the gain is high $4.43 \mathrm{~dB}$ when an antenna is placed far away from the human head and the cylindrical slot microstrip patch antenna also provides less SAR of $0.00109 \mathrm{~W} / \mathrm{Kg}$. 
Table.2. Results of the proposed antennas

\begin{tabular}{|c|c|c|c|}
\hline \multirow{2}{*}{ Antennas } & \multirow{2}{*}{$\begin{array}{c}\text { Resonant } \\
\text { frequency (GHz) }\end{array}$} & $\begin{array}{c}|c| \\
\text { Gain (dB) } \\
\text { proximity }\end{array}$ & $\begin{array}{c}\text { Far } \\
\text { proximity }\end{array}$ \\
\hline \multirow{2}{*}{$\begin{array}{c}\text { Vertical slot } \\
\text { MPA }\end{array}$} & 10.846 & 2.83 & 4.2 \\
\cline { 2 - 4 } & 16.452 & 1.82 & 2.48 \\
\hline \multirow{2}{*}{$\begin{array}{c}\text { Cylindrical slot } \\
\text { MPA }\end{array}$} & 10.846 & 3.06 & 4.43 \\
\cline { 2 - 4 } & 16.452 & 2.19 & 3.41 \\
\hline
\end{tabular}

Table.3. Specific Absorption Rates

\begin{tabular}{|c|c|c|c|}
\hline \multirow[b]{2}{*}{ Antennas } & \multirow{2}{*}{$\begin{array}{l}\text { Resonant } \\
\text { frequency }(\mathbf{G H z})\end{array}$} & \multicolumn{2}{|c|}{ SAR (W/Kg) } \\
\hline & & $\begin{array}{c}\text { Close } \\
\text { proximity }\end{array}$ & $\begin{array}{c}\text { Far } \\
\text { proximity }\end{array}$ \\
\hline \multirow{2}{*}{$\begin{array}{l}\text { Vertical slot } \\
\text { MPA }\end{array}$} & 10.846 & 0.0309 & 0.00851 \\
\hline & 16.452 & 0.019 & 0.00159 \\
\hline \multirow{2}{*}{$\begin{array}{c}\text { Cylindrical slot } \\
\text { MPA }\end{array}$} & 10.846 & 0.0149 & 0.00546 \\
\hline & 16.452 & 0.0204 & 0.00109 \\
\hline
\end{tabular}

\section{CONCLUSIONS}

In this paper specific absorption rate that is the amount of radiation absorbed by the human head is calculated by designing rectangular shaped microstrip patch antenna as vertical slot and cylindrical slot antennas. Simulation is done by using CST (Computer Simulation Technology) tool. The human head model is designed with six layers - Scalp, Fat, Skull, Dura, CSF, Brain and the specific absorption rate is calculated for $1 \mathrm{~g}$ of tissue as per the IEEE Standard. The SAR value is less for cylindrical slot microstrip patch antenna i.e. $0.00109 \mathrm{~W} / \mathrm{Kg}$ at $16.452 \mathrm{GHz}$ when an antenna is placed far away from the human head model, and it is observed that the human head absorbs less radiation while placing an antenna far away from the human head. The vertical slot microstrip patch antenna provides the SAR value of $0.00159 \mathrm{~W} / \mathrm{Kg}$ at $16.452 \mathrm{GHz}$ when an antenna placed far away from the human head. From the designed antennas the cylindrical slot micro strip patch antenna provides high gain i.e. $4.43 \mathrm{~dB}$ at $10.846 \mathrm{GHz}$ while placing an antenna far away $(10 \mathrm{~m})$ from the human head. The vertical slot microstrip patch antenna provides the gain of $4.2 \mathrm{~dB}$ at $10.846 \mathrm{GHz}$. In future, the proposed antenna may be further developed to evaluate the SAR for different parts of the body including the blood and water content. Further the designed antenna will be tested future using cSAR3D-A system for automated calculation of SAR range as well as DASY SAR measurement system used for manual testing of an antenna and its performance.

\section{REFERENCES}

[1] Nur Ilham Aliyaa Ishak, Norhudah Seman, Mohammad Ramlee Kamarudin and Noor Asmawathi Samsuri, "Specific Absorption Rate Investigation on Multiple Antennas", Proceedings of International Symposium on Antennas and Propagations, pp. 1-2, 2017.

[2] Israa H. Ali, Huda I. Hamd and Ali I. Abdalla, "Design and Comparison of Two Types of Antennas for SAR Calculation in Wireless Applications", Proceedings of International Conference on Advances in Science and Engineering Technology, pp. 1-6, 2018.

[3] Anu Tharakan, J. Deepthi, A. Divya Sebastian, J. Gopika and D.D. Krishna, "Specific Absorption Rate (SAR) Reduced Mobile Phone Antenna Designs", Proceedings of $5^{\text {th }}$ International Conferences on Advances in Computing and Communications, pp. 23-28, 2015.

[4] K.S. Sultan, H.H. Abdullah and A.A. Abdallah, "Low SAR, Simple Printed Compact Multiband Antenna for Mobile and Wireless Communication Applications", International Journal of Antennas and Propagation, Vol. 2014, pp. 1-8, 2014.

[5] Shivalingappa M. Baligar, Rajendra Soloni and D.N. Chandrappa, "Analysis of Specific Absorption Rate (SAR) of Microstrip Patch Antenna for Wireless Applications", International Journal of Advanced Research in Computer and Communication Engineering, Vol. 5, No. 5, pp. 43-52, 2016.

[6] Ashok Gundumulla, Sachin Agrawal and Manoj Singh Parihar, "Miniaturized Active Stepped Impedance Planar Inverted F- Antenna using Common Ground", International Journal of Electronics and Communications, Vol. 83, pp. 233-239, 2017.

[7] M.R. Iqbal Faruque, N. Aisyah Husni, Md. Lkbal Hossain, M. Tariqul Islam and N. Misran, "Effects of Mobile Phone Radiation onto Human Head with Variation of Holding Cheek and Tilt Positions", Journal of Applied Research and Technology, Vol. 12, No. 5, pp. 871-876, 2014.

[8] Md. Iqbal Hossain, M.R. Iqbal Faruque and M Tariqul Islam, "Investigation of Hand Impact on PIFA Performance and SAR in the Human Head", Journal of Applied Research and Technology, Vol. 13, No. 4, pp. 447-453, 2015.

[9] Stanisalv Kovar, Ivan Spano, Gianluca Gatto, Jan Valouch and Milan Adamek, "SAR Evaluation of Wireless Antenna on Implanted Cardiac Pacemaker", Journal of Electromagnetic Waves and Applications, Vol. 31, No. 6, pp. 627-635, 2017.

[10] Sahar Aqeel Abdulrazzaq and Jabir S. Aziz, "SAR Simulation in the Human Head Exposed to RF Signals and Safety Precautions", International Journal of Computer Science Engineering and Technology, Vol. 3, No. 9, pp. 334340, 2013. 